\title{
Effects of dietary bentonite on improvements in hema- tology and enzyme in copper exposed rainbow trout (Oncorhynchus mykiss)
}

\author{
Arzu Ucar ${ }^{1}$, Muhammed Atamanalp ${ }^{2}$, Esat Mahmut Kocaman ${ }^{3}$, Gonca Alak ${ }^{4}$, Ahmet Topal ${ }^{5}$, \\ Ozden Fakioglu ${ }^{6}$, Veysel Parlak ${ }^{7}$, Telat Yanik ${ }^{8^{*}}$
}

1, 2, 3, 4, 5, 6, 7, 8 Faculty of Fisheries, Ataturk University, Erzurum, Turkey

\section{Keywords \\ Rainbow trout \\ Bentonite \\ Copper toxicity \\ Fish physiology}

Received: 5 April 2019

Accepted: 10 May 2019

Published: 10 June 2019

\begin{abstract}
This research was conducted to determine the effects of dietary bentonite on copper toxicity in rainbow trout (Oncorhynchus mykiss). Fish were fed with a commercial feed including 0,500 and $1000 \mathrm{mg} / \mathrm{kg} \mathrm{Cu}$ and 0,1 and $2 \%$ bentonite for 4 months. Final evaluation was made by determining hematology and enzyme activities. It was determined that bentonite did not prevent the toxicity of fish in the presence of $1000 \mathrm{mg} / \mathrm{kg}$ copper since there were significant changes in enzyme activities of fish. It may be suggested that adding $2 \%$ bentonite to fish feeds prevents $\mathrm{Cu}$ toxicity. Further studies are needed in different fish species living various environments in order to introduce it commercially.
\end{abstract}

(c) 2019 The Author(s). Published by TAF Publishing.

\section{INTRODUCTION}

Rapid changes in aquaculture sector requires some necessities related to fish feed and put pressure on researchers to search new ways to increase the total production without disturbing fish health. Economically and sustainable aquaculture is promoted, in particular in feed studies, by using different feed additives. Usage of organic products in the aquaculture sector have been increasing from last decade. Copper $(\mathrm{Cu})$ is an essential trace element found in small amounts in a variety of cells and tissues with the highest concentrations in the liver $[1,2,3]$. Studies on copper toxicity have reported that this metal reduce fish resistance to certain diseases, change swimming behavior, cause oxidative stress, effects osmoregulation, blood structure, and enzyme activity [4].

Since fish is an important food source for humans and other organisms, physiological and biochemical changes in fish is important for the future of the ecosystem [5]. Pollutants in aquatic environment can pose adverse effects on growth, physiology, reproduction and survival risk of aquatic organisms especially on fish [6].

Bentonites belong to a smectites group of clay minerals formed as a result of weathering of volcanic ashes [7]. Bentonite is a natural substance, economic, easy accessibility, and simple usage. In animal nutrition, clay minerals are used for their adsorption/absorption properties [8] and potent detoxifier [9]. Such characteristics of this clay indicate that there will be more use in the fisheries field in the coming years.

Although the toxic effect of copper metal has been reported in many studies, researches on the physiological effects of the bentonite clay on the rainbow trout are limited. Therefore, this research is aimed to determine the effects of bentonite on copper toxicity by testing hematology and some

*email: talatyanik@yahoo.com

${ }^{*}$ Corresponding author: Telat Yanik 
enzyme activities of juvenile rainbow trout.

\section{MATERIALS AND METHODS}

A total of 900 juvenile rainbow trout (Oncorhynchus mykiss) with $16 \pm 2$ gr were randomly replaced to research tanks. After a-15 days of acclimatization period, fish were fed with $0 \%, 1 \%$ and $2 \%$ bentonite including feeds for 12 weeks. Control group did not have bentonite and copper. Since the maximum permissible level of copper was reported as 665 $\mathrm{mg} \mathrm{Cu} / \mathrm{kg}$ by [10], feed was added 0,500 and $1000 \mathrm{mg} / \mathrm{kg}$ $\mathrm{Cu}$ based on each bentonite level.

The experimental water had neutral $\mathrm{pH}, 8$ to $9 \mathrm{mg} / \mathrm{L}$ dissolved oxygen, $10.5 \pm 0.5^{\circ} \mathrm{C}$ temperature, and $220 \mathrm{mg} / \mathrm{L}$ of total hardness.

Blood samples were collected from each tank after anesthetizing with clove oil for hematological analyzes [11]. Blood samples were analyzed hematologically and biochemically $[11,12]$. MCV, MCH and MCHC values were calculated according to [13].

Enzyme activities (G6PD and 6PGD) were determined by methods given in $[11,14,15]$.

\section{A. Statistical Analyzes}

The data were subjected to Analysis of Variance (ANOVA) by using SPSS and Duncan test used for determination of differences between means at alpha 0.05 .

\section{RESULTS}

The growth of a living can be realized by storing energy in the body, putting out digested foods, and moving some chemical substances in the body in different directions. All of these procedures are performed by the blood vessels forming the blood and blood pathways [16]. The basic functions of blood are oxygen transport to tissues, feeding of tissues, maintenance of acid-base balance and removal of metabolic waste products from tissues. For this reason, any disorder that occurs in a blood has a significant effect on the physiological activities of the whole body. Hematological parameters and enzyme activities determined from the experiment after 4 months of feeding period are shown in Table 1.

TABLE 1

HEMATOLOGY PARAMETERS AND ENZYME ACTIVITIES IN RAINBOW (MEAN \pm STANDARD DEVIATION)

\begin{tabular}{|c|c|c|c|c|c|c|c|c|c|}
\hline Bentonite (\%) & & 0 & & & 1 & & & 2 & \\
\hline Copper (mg/kg) & 0 & 500 & 1000 & 0 & 500 & 1000 & 0 & 500 & 1000 \\
\hline $\mathrm{Hb}(\mathrm{g} / 100 \mathrm{ml})$ & $8.8 \pm 0.9$ & $7.5 \pm 3.5 b c$ & $9.9 \pm 0.0 \mathrm{a}$ & $9.0 \pm 0.5 \mathrm{ab}$ & $8.9 \pm 1.0 \mathrm{ab}$ & $9.0 \pm 0.5 \mathrm{ab}$ & $10.5 \pm 0.1 \mathrm{a}$ & $9.5 \pm 0.8 \mathrm{ab}$ & $6.7 \pm 0.9 \mathrm{c}$ \\
\hline Het $(\mathrm{g} / 100 \mathrm{ml})$ & $8.5 \pm 0.6 \mathrm{~d}$ & $6.7 \pm 3.6 \mathrm{abc}$ & $9.0 \pm 0.1 \mathrm{a}$ & $8.3 \pm 0.5 \mathrm{~cd}$ & $8.3 \pm 1.2 \mathrm{abcd}$ & $6.8 \pm 1.1 \mathrm{abc}$ & $9.7 \pm 0.0 \mathrm{bcd}$ & $9.1 \pm 0.5 \mathrm{a}$ & $6.0 \pm 0.8 \mathrm{ab}$ \\
\hline $\operatorname{RBC}\left(106 / \mathrm{mm}^{3}\right)$ & $0.97 \pm 0.03 \mathrm{ab}$ & $0.81 \pm 0.4 b$ & $1.11 \pm 0.02 \mathrm{a}$ & $0.94 \pm 0.02 \mathrm{ab}$ & $0.98 \pm 0.09 \mathrm{ab}$ & $0.92 \pm 0.1 \mathrm{ab}$ & $1.13 \pm 0.02 \mathrm{a}$ & $1.06 \pm 0.09 a$ & $0.76 \pm 0.08 b$ \\
\hline WBC $\left(103 / \mathrm{mm}^{3}\right)$ & $11.7 \pm 0.5 \mathrm{ab}$ & $8.5 \pm 5.5 b$ & $13.1 \pm 0.2 \mathrm{a}$ & $11.4 \pm 0.2 \mathrm{ab}$ & $12.3 \pm 2.1 \mathrm{a}$ & $10.8 \pm 1.3 \mathrm{ab}$ & $13.7 \pm 0.1 \mathrm{a}$ & $12.7 \pm 1.2 \mathrm{a}$ & $8.5 \pm 1.5 b$ \\
\hline $\operatorname{PLT}\left(103 / \mathrm{mm}^{3}\right)$ & $229.0 \pm 56.5 \mathrm{abc}$ & $179.5 \pm 49.0 \mathrm{c}$ & $246.0 \pm 2.3 \mathrm{ab}$ & $246.5 \pm 50.2 \mathrm{ab}$ & $258.0 \pm 16.1 \mathrm{a}$ & $177.0 \pm 30.0 \mathrm{c}$ & $246.0 \pm 24.2 \mathrm{ab}$ & $244.5 \pm 22.5 \mathrm{ab}$ & $199.5 \pm 1.7 \mathrm{bc}$ \\
\hline $\operatorname{MCV}\left(\mu \mathrm{m}^{3}\right)$ & $87.5 \pm 4.0 \mathrm{a}$ & $81.8 \pm 4.0 \mathrm{bcd}$ & $80.7 \pm 3.1 \mathrm{~cd}$ & $88.7 \pm 3.3 \mathrm{a}$ & $84.3 \pm 5.0 \mathrm{abc}$ & $73.7 \pm 1.4 \mathrm{e}$ & $85.9 \pm 2.6 \mathrm{abc}$ & $86.4 \pm 2.6 \mathrm{ab}$ & $78.2 \pm 1.7 \mathrm{de}$ \\
\hline $\mathrm{MCH}(\mu \mathrm{g} /$ cell $)$ & $90.5 \pm 6.7 \mathrm{a}$ & $94.6 \pm 3.7 \mathrm{a}$ & $88.8 \pm 2.2 \mathrm{a}$ & $95.6 \pm 3.7 \mathrm{a}$ & $91.1 \pm 2.6 \mathrm{a}$ & $\begin{array}{l}100.2 \pm 21.3 \\
\text { a }\end{array}$ & $92.5 \pm 3.3 \mathrm{a}$ & $89.6 \pm 0.1 \mathrm{a}$ & $87.9 \pm 2.8 \mathrm{a}$ \\
\hline $\mathrm{MCHC}(\mu \mathrm{g} /$ cell $)$ & $126.2 \pm 10.6 \mathrm{abc}$ & $137.0 \pm 16.1 \mathrm{ab}$ & $156.6 \pm 0.7 d$ & $114.3 \pm 6.4 \mathrm{abc}$ & $143.5 \pm 0.0 \mathrm{a}$ & $112.5 \pm 2.0 \mathrm{bc}$ & $106.6 \pm 1.8 \mathrm{abc}$ & $102.2 \pm 2.5 b c$ & $101.6 \pm 10.4 \mathrm{c}$ \\
\hline $\begin{array}{l}\text { G6PD (EU/mg pro- } \\
\text { tein) }\end{array}$ & $\begin{array}{l}0.09 \pm 0.02 \\
\mathrm{~b}\end{array}$ & $\begin{array}{l}0.10 \pm 0.01 \\
\mathrm{~b}\end{array}$ & $\begin{array}{l}0.12 \pm 0.01 \\
\mathrm{~b}\end{array}$ & $\begin{array}{l}0.06 \pm 0.01 \\
b\end{array}$ & $\begin{array}{l}0.04 \pm 0.00 \\
\mathrm{~b}\end{array}$ & $\begin{array}{l}0.08 \pm 0.01 \\
\mathrm{~b}\end{array}$ & $\begin{array}{l}0.09 \pm 0.06 \\
\mathrm{~b}\end{array}$ & $\begin{array}{l}0.06 \pm 0.03 \\
b\end{array}$ & $0.30 \pm 0.04 \mathrm{a}$ \\
\hline $\begin{array}{l}6 \mathrm{PGD}(\mathrm{EU} / \mathrm{mg} \text { pro- } \\
\text { tein) }\end{array}$ & $0.07 \pm 0.00 \mathrm{bc}$ & $0.04 \pm 0.01 b c$ & $0.19 \pm 0.09 \mathrm{~b}$ & $0.05 \pm 0.04 b c$ & $0.05 \pm 0.02 b c$ & $0.15 \pm 0.01 b c$ & $0.01 \pm 0.00 \mathrm{c}$ & $0.06 \pm 0.09 \mathrm{bc}$ & $0.37 \pm 0.27 \mathrm{a}$ \\
\hline
\end{tabular}

Hemoglobin is a protein molecule in red blood cells and has duties as; carrying oxygen to the tissues of the body and carrying carbon dioxide, which produced by cells, from the tissues to organs. When the effect of copper bentonite application on hemoglobin value was investigated, it was determined that there were changes according to groups and periods, in the present research. In terms of statistics, the difference between the groups was found to be significant $(p<0.05)$.

There were fluctuations with respect to hematocrit values in all groups. The hematocrit value of the $1 \%$ bentonite added group was close to that of the control group (Table 1).

Red Blood Cells (RBC) are the largest number of blood cells.
They contain globulin and iron-containing hemoglobin to give blood red color red. Hemoglobin containing globulin and iron, give red color to blood. The most important duty of these is transporting oxygen from the gills to the tissues and carbon dioxide from the tissues to the gills, via including hemoglobin. At the end of the study period, the highest erythrocyte counts were obtained as $1.13 \pm 0.02,1.06 \pm$ 0.09 and $1.11 \pm 0.02$ in $0 \mathrm{mg} \mathrm{Cu} / \mathrm{kg}+2 \%$ Bentonite, $500 \mathrm{mg}$ $\mathrm{Cu} / \mathrm{kg}+2 \%$ Bentonite, and $1000 \mathrm{Cu} / \mathrm{kg}+0 \%$ Bentonite groups, respectively.

Leukocytes are defense cells of organisms and species with a large number of leukocyte cells are able to fight pollutants more effectively. The highest leukocyte counts were obtained in the $0 \mathrm{mg} \mathrm{Cu} / \mathrm{kg}+2 \%$ Bentonite and $1000 \mathrm{Cu} / \mathrm{kg}+$ 
$0 \%$ Bentonite groups at the end of the study period. In the current study, only the low dose of the copper group (500 $\mathrm{mg} / \mathrm{kg}$ ) showed a decrease in leukocyte number as compared to the control group. In the high dose group (1000 $\mathrm{mg} / \mathrm{kg} \mathrm{Cu}$, the highest value was reached among the other groups. This alteration was found as statistically significant. Although the amount of leukocyte increased in the bentonite added groups, similar values were obtained compared to the control.

In fish, the thrombocyte cells have phagocytic ability and participate in the defense mechanism. These cells express the intracellular and extracellular molecules, including the link between innate and subsequently acquired immunity and immunological functions.

Cell indices of erythrocytes such as MCV and MCH are used for classification of anemic situations and determination of cell activities of erythrocytes [17]. At the end of the trial, there was a decrease in the MCV value in almost all groups compared to the control. The MCH differences among the groups were found significant $(p<0.05)$. As the result of measurement of the exposed fish blood, the highest mean $\mathrm{MCH}$ value was found in as $100.2 \pm 21.3 \mathrm{pg}$ in $1000 \mathrm{mg} / \mathrm{kg}$ $\mathrm{Cu}+1 \%$ bentonite group and the lowest $\mathrm{MCH}$ was found as $87.9 \pm 2.8 \mathrm{pg}$ in the $1000 \mathrm{mg} / \mathrm{kg} \mathrm{Cu}+2 \%$ bentonite group. The MCHC value associated with hemoglobin content was highest in $1000 \mathrm{mg} / \mathrm{kg} \mathrm{Cu}+1 \%$ bentonite group as $136.3 \pm$ $31.6 \mathrm{~g} / 100 \mathrm{ml}$, at the end of the trial period.

The livings are equipped with an Antioxidant Defense System (ASS), which contains several enzymes and vitamins to protect them from the effects of oxidative stress. Important enzymes of carbohydrate metabolism are Glucose-6-Phosphate Dehydrogenase (G6PD) and 6-Phosphogluconate Dehydrogenase (6PGD). G6PD, the first enzyme of the pentose phosphate pathway, is an important antioxidant enzyme involved in the cellular defense mechanism against oxygen cytotoxicity [18].

The pentose phosphate pathway is quite important in that it is the only oxidative pathway for glucose oxidation in cells with a basic energy source glucose, such as erythrocytes and brain cells, composed of two different stages that perform two specific functions.

The first stage is the oxidative and irreversible phase; at this stage, G6P is transformed into pentose phosphates and $\mathrm{CO}_{2}$; NADP + is reduced to NADPH. The second phase is a non-oxidative and reversible state; in which the pentose phosphates are converted into glycolytic intermediates. The speed and direction of reactions in the pentose phosphate pathway will vary depending on the requirement for intermediate products. Another important function of the pentose phosphate pathway is the synthesis of ribose5-phosphate, which is required for DNA and RNA synthesis. In terms of G6PD and 6PGD enzyme activities in the present study, highest values were obtained in the $1000 \mathrm{Cu} / \mathrm{kg}+0 \%$ Bentonite group and $1000 \mathrm{Cu} / \mathrm{kg}+2 \%$ Bentonite group at the end of the trial period.

\section{DISCUSSION}

Clay mineral can increase pellet rate durability when added to complete feed at concentrations of between 1 and $5 \%$ [19]. Since bentonite is authorized for use as anti-caking agents in food and can be reasonably assumed to demonstrate similar properties when applied to feed or feed materials [20].

Hematocrit is expressed as a percentage of the volume of erythrocytes in blood. It is an important parameter because of reflecting the oxygen carrying capacity of blood and the function of erythropoietic tissues. Changes in dehydration, nutrition, erythrocyte synthesis, and membrane permeability cause changes in hematocrit levels. Hemodilution (increase in the proportion of water present in blood) is defined as a mechanism to reduce the concentration of foreign substances in circulatory systems. Some reports say that; decreased hematocrit levels may be a consequence of increased blood volume in the blood tissue as well as reduced hematocrit levels in the contaminating effect may be due to hemodilution due to disorder in osmoregulation, osmotic hemolysis of erythrocytes or impairment of hemoglobin synthesis by affecting iron metabolism [21, 22, 23].

Rehulka [24] reported that the percentage of hematocrit in healthy trout (O. mykiss) ranged from $29.4 \%$ to $41.1 \%$. Similarly, McCarthy et al., [25] reported that the hematocrit value in healthy rainbow trout ( 0 . mykiss) varied between $30-49 \%$. It has been determined that chemical applications reduce hematocrit in different fish species [26, 27, 28, 29]. The findings we have obtained from our study are consistent with these literatures. In most cases dietborne metal has produced no significant effects $[10,30,31]$ observed slight reductions in hematocrit and/or hemoglobin with increasing dietary $\mathrm{Cu}$ concentrations.

Hematological parameters such as the erythrocyte count, hematocrit value, and hemoglobin concentration are very reliable indicators for determining the oxygen-carrying case as well as metal contamination in the aquatic environment. In the present study, it is thought that the decrease in the rainbow trout's erythrocyte count, hematocrit value, and hemoglobin concentration is caused by a decrease in the hem protein synthesis and the anemic state. It has been reported that changes in hematologic parameters may be 
due to hematopoietic tissue deterioration as well as osmotic changes induced by metal toxicity [32]. Gill and Epple[33] reported that anemia with membrane permeability alteration and erythrocyte disintegration triggered metal toxicity. In addition, they reported that metal damaged erythropoiesis due to the toxic effect of hematopoietic tissues such as the kidney and spleen. The decrease in blood cells and hemoglobin suggests that the pollutant is hemotoxic effective to fish.

The number of leukocyte cells is influenced by physiological and environmental factors. One of the most common responses in fish exposed to toxic substances is the reduction in the percentage of lymphocytes and the increase in heterophils [21]. Aquatic contaminants suppress activation and immune system of fish with a great variety according to the duration of pollutants exposure, toxic substance concentration, and fish species [34].

Platelets play an important role in hemostasis (stop bleeding) and in the blood clotting process. In case of bleeding due to adhesive formation, they form a plug. Serotonin from the pulp-forming influences the vessel walls, narrowing the veins and thus reducing blood loss. Coagulation time for teleost fish is 5 minutes. In the case of stress, the blood coagulation system is more active in fish, which can increase the platelets count. Thrombocytopenia has negative effects on fish. Because these cells are not only responsible for blood clotting but also for controlling the fluid flowing from the superficial wounds in the fish. High levels of glucocorticoids cause a decrease in the number of platelets and an increase in clotting time. The causes of this increase and decrease are valid within the platelet values obtained from our study. Erythrocyte indices (MCV, MCH, MCHC) are associated with hematocrit, erythrocyte count, the density of hemoglobin and indicate the size or diameter of erythrocytes and the amount of hemoglobin. These indexes help in the differential diagnosis of anemia types. These anemia types are shaped like this; Macrociter anemia in the case of increased MCV values, micrositer anemia in case of MCV values decrease, hyperchromic in case of increase of MCH values, hypochloremia in case of MCH decrease.

The importance of G6PD and 6PGD in metabolism has been known for many years. For the production of enzymes in the
GSH antioxidant defense mechanism, NADP is used, which is synthesized in the pentose phosphate metabolic pathway with G6PD and 6PGD combination. Therefore, G6PD and 6PGD are thought to be antioxidant enzymes. G6PD and 6PGD enzymes have been found to decrease significantly in fish exposed to pollution. These enzymes are the first enzymes of the pentose phosphate pathway and the change in their amounts is being the potential targets of toxic chemicals [35].

In fish, enzyme activities vary depending on tissue, metal concentration and duration. It is believed that at all tested bentonite concentrations, G6PD and 6PGD activities giving close results to the control group may be effective by the inactivation of bentonite metal-binding proteins and MT.

The increase in groups A7 and A9 can be interpreted as a result of these enzymes reacting immediately to oxyradicals that are introduced into fish by metals [36].

At the anemia, tissue oxygen hypoxia develops as the blood's oxygen transport capacity decreases and the amount of oxygen required for the tissues decreases. Because of the hypoxic effect, the functions of the tissues are impaired; so the statement of the anomaly occurs in many systems. Hemolysis; is the destruction of erythrocytes before their normal lifespan is complete. Young erythrocytes have richer G6PD content than the mature erythrocytes. If the activity of the enzymes is impaired, the old erythrocytes disappear in the transition to the hemolytic phase. Since reticulocytes released to renew lost cells have a high enzyme level, an increase in enzyme activity can be observed at this stage [37].

\section{CONCLUSION}

It has been observed that bentonite application causes changes in enzyme activities, hematological indexes of fish. But it is not clear to what mechanism bentonite influences these parameters. We think that this effect may originate directly or indirectly through some intermediate routes. It needs for further and more detailed studies to better explain this mechanism.

\section{ACKNOWLEDGMENT}

This work was supported by TUBITAK with Project number: 1160126.

\section{REFERENCES}

[1] J. R. Turnlund, "Human whole-body copper metabolism," The American Journal of Clinical Nutrition, vol. 67, no. 5, pp. 960S-964S, 1998. doi: https://doi.org/10.1093/ajcn/67.5.960s

[2] G. F. Nordberg, B. A. Fowler, and M. Nordberg, Handbook on the Toxicology of Metals. New York, NY: Academic Press, 2014. 
[3] N. Maneechot, W. Supiwong, and A. Tanomtong, "Chromosomal analysis and nors polymorphism of bagarius suchus (siluriformes: Sisoridae) by conventional banding and fish techniques," Journal of Applied and Physical Sciences, vol. 2, no. 1, pp. 10-19, 2016. doi: https://doi.org/10.20474/-japs2.1.2

[4] K. B. Tierney, D. H. Baldwin, T. J. Hara, P. S. Ross, N. L. Scholz, and C. J. Kennedy, "Olfactory toxicity in fishes," Aquatic Toxicology, vol. 96, no. 1, pp. 2-26, 2010. doi: https://doi.org/10.1016/j.aquatox.2009.09.019

[5] S. Afshan, S. Ali, U. S. Ameen, M. Farid, S. A. Bharwana, F. Hannan, and R. Ahmad, "Effect of different heavy metal pollution on fish," Research Journal of Chemical and Environmental Sciences, vol. 2, no. 1, pp. 74-79, 2014.

[6] N. Malik, A. Biswas, T. Qureshi, K. Borana, and R. Virha, "Bioaccumulation of heavy metals in fish tissues of a freshwater lake of Bhopal," Environmental Monitoring and Assessment, vol. 160, no. 1-4, pp. 267-276, 2010. doi: https://doi.org/ 10.1007/s10661-008-0693-8

[7] F. Bergaya and G. Lagaly, Handbook of Clay Science, Elsevier. Amsterdam, Netherland: Sage Publications, 2013.

[8] R. Slamova, M. Trckova, H. Vondruskova, Z. Zraly, and I. Pavlik, "Clay minerals in animal nutrition," Applied Clay Science, vol. 51, no. 4, pp. 395-398, 2011. doi: https://doi.org/10.1016/j.clay.2011.01.005

[9] B. Sun, B. Ranganathan, and S.-S. Feng, “Multifunctional poly (D, L-lactide-co-glycolide)/montmorillonite (PLGA/MMT) nanoparticles decorated by trastuzumab for targeted chemotherapy of breast cancer," Biomaterials, vol. 29, no. 4, pp. 475-486, 2008. doi: https://doi.org/10.1016/j.biomaterials.2007.09.038

[10] R. Lanno, S. Slinger, and J. Hilton, "Maximum tolerable and toxicity levels of dietary copper in rainbow trout (Salmo gairdneri Richardson)," Aquaculture, vol. 49, no. 3-4, pp. 257-268, 1985. doi: https://doi.org/10.1016/0044-8486(85) 90084-5

[11] A. Ucar, M. Atamanalp et al., "The effects of natural (clove oil) and synthetical(2-phenoxyethanol) anesthesia substances on hematology parameters of rainbow trout (Oncorhynchus mykiss) and brown trout (Salmo trutta fario)," Journal of Animal and Veterinary Advances, vol. 9, no. 14, pp. 1925-1933, 2010. doi: https://doi.org/10.3923/javaa. 2010.1925.1933

[12] P. Blaxhall and K. Daisley, “Routine haematological methods for use with fish blood," Journal of Fish Biology, vol. 5, no. 6, pp. 771-781, 1973. doi: https://doi.org/10.1111/j.1095-8649.1973.tb04510.x

[13] M. Morris and F. Davey, "Chapter 24: Basic examination of the blood," in Clinical Diagnosis and Management by Laboratory Methods. California, CA: WB Saunders, 1996.

[14] E. Beutler, Red Cell Metabolism: A Manual of Biochemical Methods. New York, NY: Grune \& Stratton, 1984.

[15] A. Uçar, M. Atamanalp, M. Cankaya, and H. Özdemir, "Effects of anesthetic substances on some antioxidan enzyme activities of trouts/anestezik maddelerin alabaliklarda bazi antioksidan enzim aktivitelerinin üzerine etkileri," Journal of Fisheries Sciences, vol. 7, no. 2, p. 152, 2013. doi: https://doi.org/10.3153/jfscom.2013016

[16] E. Yilmaz, "A review on the effect of some medicinal plants added to fish hematology and eating to the blood parameters of fish," Science, vol. 36, no. 2, pp. 45-60, 2015.

[17] A. Şahan and İ. Cengizler, "Determination of some haematological parameters in spotted barb (capoeta barroisi lortet, 1894) and roach (rutilus rutilus, linnaeus, 1758) living in Seyhan River (Adana City Region)," Turkish Journal of Veterinary and Animal Sciences, vol. 26, no. 4, pp. 849-858, 2002.

[18] S. Yilmaz and İ. H. Bahceciogiu, "Lipid peroxidation, antioxidant enzymes and pyruvate kinase activity in rats with carbon tetrachloride-induced cirrhosis," Turkish Journal of Veterinary and Animal Sciences, vol. 24, no. 1, pp. 25-28, 2000.

[19] M. O. Ayoola, "Application of dietary bentonite clay as feed addictive on feed quality, water quality and production performance of African catfish (Clarias gariepinus)," Stellenbosch University, Stellenbosch, South Africa, Unpublished doctoral dissertation, 2016.

[20] European Food Safety Authority, "Scientific opinion on the safety and efficacy of bentonite as a technological feed additive for all species," 2012. [Online]. Available: https://bit.ly/3fs0p87

[21] M. Witeska, "Stress in fish-hematological and immunological effects of heavy metals," Electronic Journal of Ichthyology, vol. 1, no. 1, pp. 35-41, 2005. doi: https://doi.org/10.1007/s10695-008-9284-4

[22] M. Atamanalp, "Investigation of chronic effects of alfa-cypermethrin on haemototoxıc parameters in the rainbow trout (Oncorhynchus mykiss)," Aquaculture Studies, vol. 17, no. 3, pp. 259-272, 2017.

[23] G. Alak, V. Parlak, M. E. Aslan, A. Ucar, M. Atamanalp, and H. Turkez, “Borax supplementation alleviates hematotoxicity 
and DNA damage in rainbow trout (Oncorhynchus mykiss) exposed to copper," Biological Trace Element Research, vol. 187, no. 2, pp. 536-542, 2019. doi: https://doi.org/10.1007/s12011-018-1399-6

[24] J. Rehulka, "Haematological analyses in rainbow trout (Oncorhynchus mykiss) affected by Viral Haemorrhagic Septicaemia (VHS)," Diseases of Aquatic Organisms, vol. 56, no. 3, pp. 185-193, 2003. doi: https://doi.org/10.3354/ dao056185

[25] D. McCarthy, J. Stevenson, and M. Roberts, "Some blood parameters of the rainbow trout (salmo gairdneri richardson) i. the kamloops variety," Journal of Fish Biology, vol. 5, no. 1, pp. 1-8, 1973. doi: https://doi.org/10.1111/j.1095-8649. 1973.tb04425.x

[26] P. M. Reddy and M. Bashamohideen, "Fenvalerate and cypermethrin induced changes in the haematological parameters of Cyprinus carpio," Acta Hydrochimica et Hydrobiologica, vol. 17, no. 1, pp. 101-107, 1989. doi: https://doi.org/10. 1002/aheh.19890170116

[27] F. Ahmad, S. S. Ali, and A. R. Shakoori, "Sublethal effects of danitol (fenpropathrin), a synthetic pyrethroid, on chinese grass carp, ctenopharyngodon idella," Folia Biologica Krakow, vol. 43, no. 6, pp. 151-160, 1995.

[28] A. Shakoori, A. Mughal, and M. Iqbal, "Effects of sublethal doses of fenvalerate (a synthetic pyrethroid) administered continuously for four weeks on the blood, liver, and muscles of a freshwater fish, ctenopharyngodon idella," Bulletin of Environmental Contamination and Toxicology, vol. 57, no. 3, pp. 487-494, 1996. doi: https://doi.org/10.1007/ s001289900216

[29] M. Atamanalp and T. Yanik, "Alterations in hematological parameters of rainbow trout (Oncorhynchus mykiss) exposed to mancozeb," Turkish Journal of Veterinary and Animal Sciences, vol. 27, no. 5, pp. 1213-1217, 2003.

[30] T. Murai, J. W. Andrews, and R. G. Smith Jr, "Effects of dietary copper on channel catfish," Aquaculture, vol. 22, pp. 353-357, 1981. doi: https://doi.org/10.1016/0044-8486(81)90161-7

[31] D. Knox, C. B. Cowey, and J. W. Adron, "Effects of dietary copper and copper: Zinc ratio on rainbow trout salmo gairdneri," Aquaculture, vol. 27, no. 2, pp. 111-119, 1982. doi: https://doi.org/10.1016/0044-8486(82)90130-2

[32] S. L. Shah, "Hematological parameters in tench tinca tinca after short term exposure to lead," Journal of Applied Toxicology: An International Journal, vol. 26, no. 3, pp. 223-228, 2006. doi: https://doi.org/10.1002/jat.1129

[33] T. S. Gill and A. Epple, "Stress-related changes in the hematological profile of the american eel (anguilla rostrata)," Ecotoxicology and Environmental Safety, vol. 25, no. 2, pp. 227-235, 1993. doi: https://doi.org/10.1006/eesa.1993. 1021

[34] A. Cuesta, J. Meseguer, and M. A. Esteban, "The antimicrobial peptide hepcidin exerts an important role in the innate immunity against bacteria in the bony fish gilthead seabream," Molecular Immunology, vol. 45, no. 8, pp. 2333-2342, 2008. doi: https://doi.org/10.1016/j.molimm.2007.11.007

[35] R. Reiter, L. Tang, J. J. Garcia, and A. Muñoz-Hoyos, "Pharmacological actions of melatonin in oxygen radical pathophysiology," Life Sciences, vol. 60, no. 25, pp. 2255-2271, 1997. doi: https://doi.org/10.1016/s0024-3205(97)00030-1

[36] T. Yuzereroglu, "Cadmium, copper and cadmium-copper interactions during accumulation, elimination and effects of metals on antioxidant enzyme activities in tissues and organs of oreochromis niloticus," Department of Biology, Cukurova University, Adana, Turkey, Unpublished doctoral dissertation, 2011.

[37] H. Varley et al., Practical Clinical Biochemistry. London, UK: William Heine-mann Medical Books, Ltd. 